American Journal of Applied Sciences 3 (12): 2167-2169, 2006

ISSN 1546-9239

(c) 2006 Science Publications

\title{
Characteristic and the Efficiency of Fuel Cell
}

\author{
Muzamir Isa, Baharuddin Ismail, Ismail Daut, Mohd Rafi Adzman and Mohd Fayzul Mohammed \\ School of Electrical System Engineering, KUKUM, Malaysia
}

\begin{abstract}
The aim of this study was to deliver information about the features of fuel cells. Along with it, this study gives details about activities of renewable energy. It covers analysis of theories and some experiments done using a set of tool called Hydro Genius Teach. The experiments are about advantages of fuel cells compared to other methods that have been used to produce electrical energy from the processes of renewable energy. Furthermore, methods on how fuel cells operate are also given. The main objective of this study is to analyse current usage of renewable energy in the world. The main focus is to do analysis on features of fuel cells as one of ways in renewable energy.
\end{abstract}

Key words: Fuel cell, hydrogen fuel cell and renewable energy

\section{INTRODUCTION}

At present, the large-scale use of fossil fuels is a dominant feature of industrial societies. It is regarded as essential for the growing, distribution and preparation of foods, for construction, manufacturing, communication and organization and many other activities.

As we have seen, modern societies and particularly industrial societies, are now totally dependent upon the use of large quantities of energy, most of it in the form of fossil fuels, for virtually all aspects of life. In 1992, the estimated total world consumption of primary energy, in all forms, was approximately 400 Energy Joule (EJ) per year, equivalent to some 9500 million tones of oil per year ${ }^{[1]}$.

Assuming a world population of about 5300 million in that year, this gives an annual average fuel use for energy man, woman and child in the world equivalent to about 1.8 tones of oil. A breakdown of world primary energy consumption by source in 1992 is shown in Fig. 1.

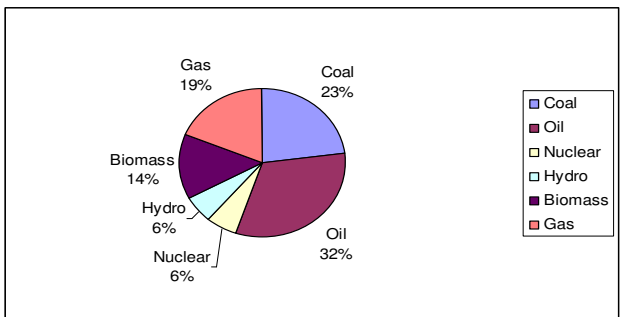

Fig. 1: World primary energy breakdowns ${ }^{[1]}$

Oil is the dominant fuel, contributing some $32 \%$, followed by coal at $23 \%$. Coal was once the dominant world fuel, but is now losing ground rapidly to oil and gas, which has a $19 \%$ share.

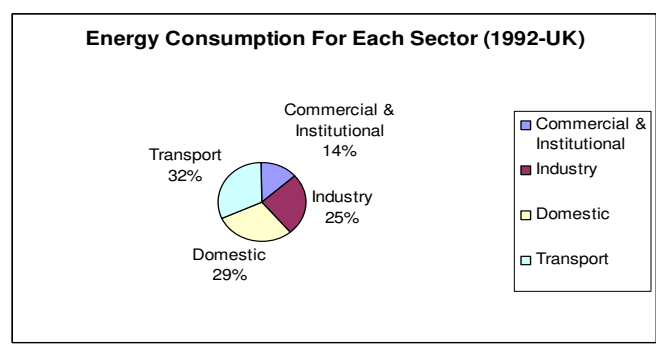

Fig. 2: Energy consumption by sector ${ }^{[1]}$

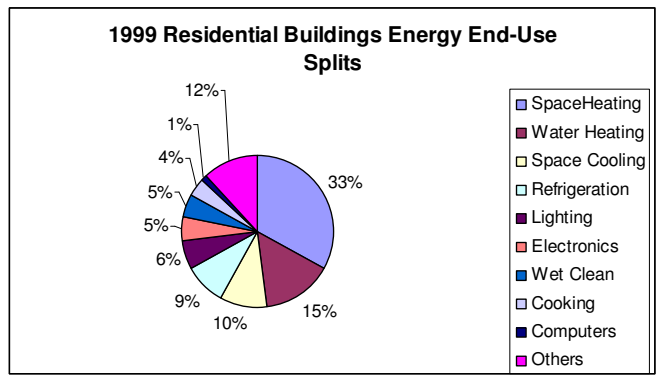

Fig. 3: $\quad$ Energy breakdowns in houses ${ }^{[1]}$

Hydroelectricity and nuclear are used much less, at around $6 \%$ each. The estimated share of traditional noncommercial fuels such as biomass is around 14\%.

The first question to consider is how much energy is used by each sector. The domestic sector comprises the second most important energy consumer as we can see from the Fig. 2.

The principal uses of energy in the domestic sector are for space heating, water heating, cooking, lighting and electrical appliances. Most of the energy used, around $70 \%$, is for low-grade heat for space and water heating. This is generally provided directly by high-grade sources such as the electricity from thermal power plants. Figure 3 gives an overall picture of energy use in the domestic sector.

Corresponding Author: Muzamir Isa, Baharuddin Ismail, Ismail Daut, Mohd Fayzul Mohammed, School of Electrical System Engineering, KUKUM 


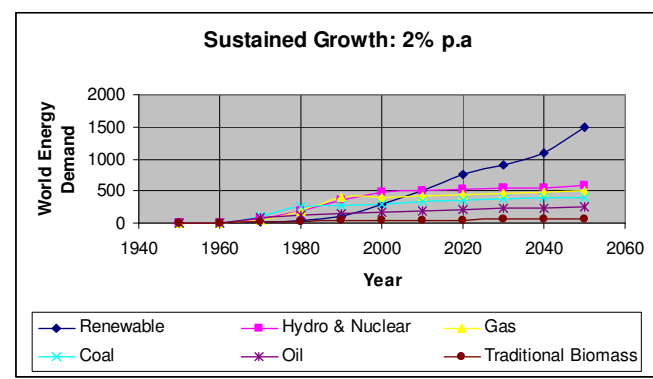

Fig. 4: World energy generations ${ }^{[1]}$

As clearly shown in Fig. 4, renewable sources are likely to make up more than $50 \%$ of the total energy supply after 2050 . While, the use of oil will start to decline after the year 2020, the message someone can get from the diagram is quite simple. The power plant for the domestic sector will need to use a fuel that can be derived from a variety of sources. This means that major structural changes are needed in the infrastructure of fuel supply and the domestic sector itself.

Summarizing all of the above it can be said that renewable energy sources seem to be a promising new way of producing energy, better and cleaner from the energy produced from burnt oil. In time to come and as the fossil fuel reserves are getting smaller, renewable source of energy will eventually bring changes worldwide in the energy sector as they may offer a solution to the matter above.

\section{MATERIALS AND METHODS}

The 'Hydro-Genius Teach' hydrogen fuel cell should be in operation approx. 10 minutes for the characteristic of the photo to take place.

* The apparatus was assembled as Fig. 5.

* The gas supply to tubes was checked to ensure it is attached correctly at the hydrogen fuel cell.

* The power supply at the electrolyser was adjusted to get the constant current (between 300 and 350 $\mathrm{mA}$ ).

* The potentiometer was varied and the respective value for voltage and current intensity was measured at various resistances.

* The potentiometer was changed with electromotor of 'Hydro-Genius Teach' as a load. The voltage and current intensity was measured when the engine runs.

\section{RESSULTS AND DISCUSSION}

Measurements and analysis: Table 12 each show the measurement of current, voltage and power in different resistance in fuel cell with electrolyser current equals to $520 \mathrm{~mA}$ and $320 \mathrm{~mA}$.

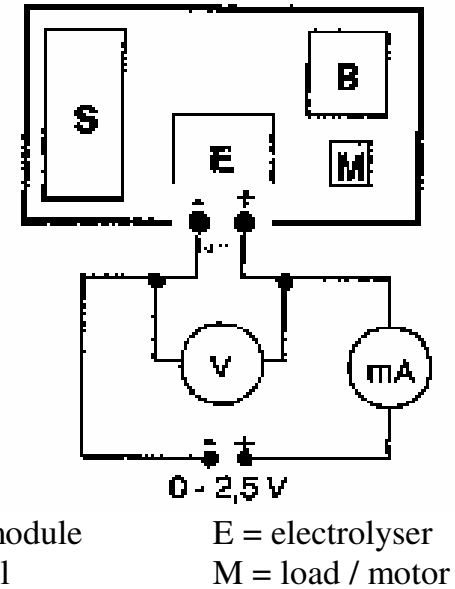

$\begin{array}{ll}\mathrm{S}=\text { solar module } & \mathrm{E}=\text { electrolyser } \\ \mathrm{B}=\text { fuel cell } & \mathrm{M}=\text { load } / \text { motor }\end{array}$

Fig. 5: Schematic connection for determining fuel cell characteristic and efficiency

Table 1: Measurement of current, voltage and power in different resistance in fuel cell with electrolyser current $=520 \mathrm{~mA}$

$\mathrm{I}$, (electrolyser) $=520 \mathrm{~mA}\left(\right.$ pure $\left.\mathrm{O}_{2}\right)$

\begin{tabular}{lccc}
$\mathrm{R}(\Omega)$ & $\mathrm{U}(\mathrm{V})$ & $\mathrm{I}(\mathrm{mA})$ & $\mathrm{P}(\mathrm{mW})$ \\
\hline 600 & 0.98 & 0 & 0 \\
300 & 0.91 & 20 & 18.2 \\
100 & 0.89 & 40 & 35.6 \\
70 & 0.87 & 60 & 52.2 \\
40 & 0.86 & 80 & 68.8 \\
10 & 0.85 & 100 & 85.0 \\
8 & 0.84 & 120 & 100.8 \\
6 & 0.83 & 140 & 116.2 \\
4 & 0.80 & 230 & 184.0 \\
motor & 0.90 & 60 & 54.0 \\
\hline
\end{tabular}

Table 2: Measurement of current, voltage and power in different resistance in fuel cells with electrolyser current $=320 \mathrm{~mA}$

$\mathrm{I},($ electrolyser $)=320 \mathrm{~mA}\left(\right.$ pure $\left.\mathrm{O}_{2}\right)$

\begin{tabular}{lccc}
$\mathrm{R}(\Omega)$ & $\mathrm{U}(\mathrm{V})$ & $\mathrm{I}(\mathrm{mA})$ & $\mathrm{P}(\mathrm{mW})$ \\
\hline 600 & 0.96 & 0 & 0 \\
300 & 0.87 & 20 & 17.4 \\
100 & 0,84 & 40 & 33.6 \\
70 & 0.82 & 60 & 49.2 \\
40 & 0.81 & 80 & 64.8 \\
10 & 0.80 & 100 & 80.0 \\
8 & 0.79 & 120 & 94.8 \\
6 & 0.78 & 140 & 109.2 \\
4 & 0.75 & 230 & 172.5 \\
motor & 0.83 & 55 & 45.7 \\
\hline
\end{tabular}

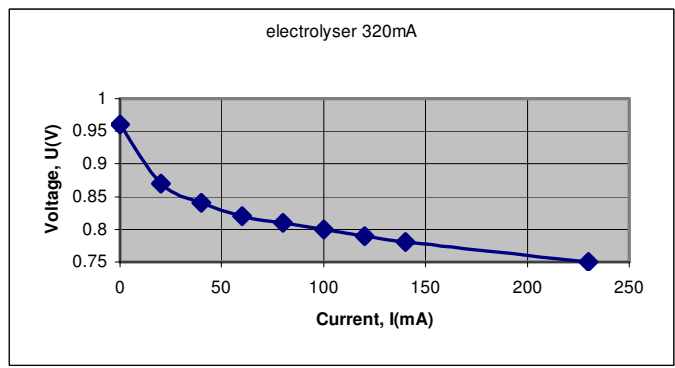

Fig. 6: Current and voltage behaviour in fuel cell for electrolyser current $320 \mathrm{~mA}$ 


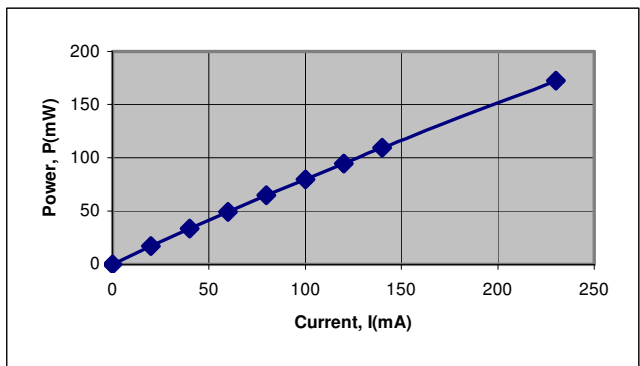

Fig. 7: Characteristic of power in fuel cell for electrolyser current $320 \mathrm{~mA}$

Figure 6 shows the characteristic of current and voltage behavior in fuel cell using $320 \mathrm{~mA}$ electrolyser current. The voltage decreased when the current increased. Fuel cell voltage efficiency using $320 \mathrm{~mA}$ electrolyser current can be calculated as follows;

$\eta=($ Actual voltage / Theoretical voltage $) * 100 \%$

$=\left(\mathrm{E}_{\mathrm{K}} / \mathrm{E}_{\mathrm{O}}\right) * 100 \%$

$=(0.96 / 1.23) * 100 \%$

$=78.05 \%$

To understand the characteristic of the hydrogen fuel cell one should have known the characteristic of the electrolysis. The process in the hydrogen fuel cell is the reversal to the electrolysis. During the electrolysis of water at least 1.23 volts must be applied. For the decomposition of water at the beginning and as a rule, the voltage is even higher (overload).

For the same reasons, lower voltage will be produced by a hydrogen fuel cell (same as galvanic cell). The characteristic of the electrodes material (catalysis), the internal resistance, the temperature and also the quantity of the hydrogen and oxygen will be influenced. For none or at very low current when the voltage of the hydrogen fuel cell is between $0.9-1.0 \mathrm{~V}$, one describes this voltage as open circuit voltage (in analogy to the battery). It is strongly dependent on the set and purity of the gasses brought in at the hydrogen fuel cell. The more one takes current from the hydrogen fuel cell, the smaller the voltage becomes. An exponential increase of the current arises in the context of reduction of the voltage.

Figure 7 represents a P-I diagram for the operating point of the electromotor. It can be then seen that the engine does not run in the optimal point, in example hydrogen is lost here.

In practice, one endeavors to operate the hydrogen fuel cell at higher current (that is high power). However, the degree of effectiveness of a hydrogen fuel cell relieves at high current. Simultaneously, so that also here the task is to find an optimal operating point (high degree of effectiveness, high performance).

Energy fuelled the industrial revolution and has continued to drive economic development. Figure 8 shows the close link between economic prosperity and energy use especially electricity. The graph also shows how greenhouse gas emissions also followed the curve

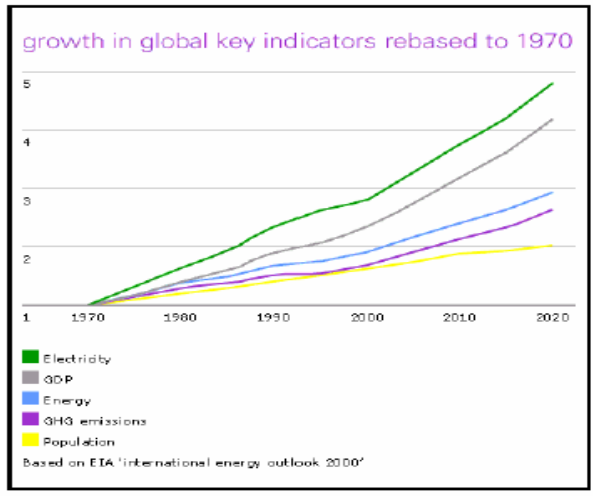

Fig. 8: Growth in global key indicators rebased to $1970^{[1]}$

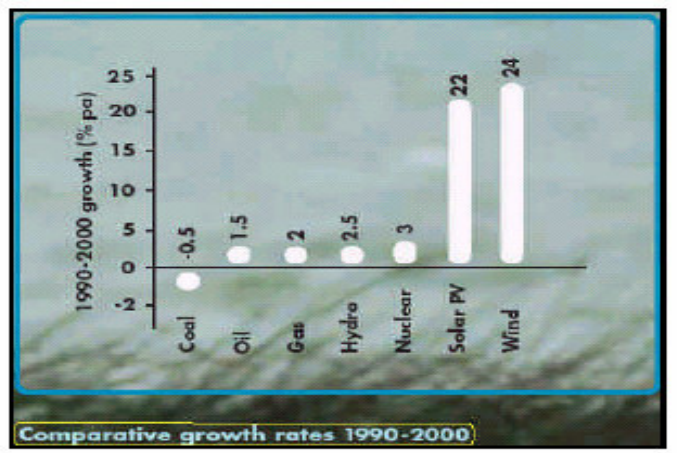

Fig. 9: Growth rates of energy sources ${ }^{[1]}$

of energy use and are expected to continue to rise even without stringent action to limit emissions.

Clean, renewable energy is the ultimate goal. But this is a long way off as the graph shows in Fig. 9. Hydrocarbons are expected to remain as the dominant source of energy for several decades.

\section{CONCLUSION}

This study has illustrated the potential of a hydrogen and fuel cell storage system for electricity. With this analysis we see that a system like this not only work effectively but also to provide a more environmental friendly solution for the future. The difference between the battery and the fuel cell system lie in the environmental concerns of the two systems. We concluded that the fuel cell system is a more environmental system than the battery because the materials that are used together with the high reliability and effective operation give a greater lifetime than the battery system.

In the past, the limiting factors of renewable energy have been the storage and transport of that energy. With the use of fuel cells and hydrogen technology, electrical power from renewable energy sources can be delivered where and when required, cleanly, efficiently and in a sustainable manner.

\section{REFERENCES}

1. Bouzoukas, A., 2003. Renewable Hydrogen Energy System For Household Applications. University of Strathclyde, Master Thesis, pp: 100115 